\title{
Widely Metastatic Parotid Acinic Cell Carcinoma to Bone and Liver: A Case Report, Review of Literature, and Review of Diagnostic Challenges
}

Vanda Farahmand Torous, Rachel Conrad, Hanlin L Wang and David Y Lu*

Department of Pathology and Laboratory Medicine, David Geffen School of Medicine at UCLA, 10833 Le Conte Ave, 13-145G CHS Los Angeles, CA 90095-1732, USA

\begin{abstract}
Distant metastasis of salivary gland neoplasms is a rare occurrence. Generally, high-grade salivary malignancies such as salivary duct carcinoma and high-grade mucoepidermoid carcinoma, as well as tumors located in the submandibular gland, show a higher likelihood of metastasizing. Acinic cell carcinoma is an uncommon salivary gland neoplasm that typically occurs in the parotid gland and is considered a low-grade malignancy. Metastasis is unusual and, if present, predominantly involves the lung and bones. However, vertebral metastasis is exceedingly rare. Here, we describe a rare case of recurrent acinic cell carcinoma of the parotid gland with widespread metastases to multiple bones, including the vertebrae, and to the liver, which was diagnosed in part by cytology. To our knowledge, this is the first report in the cytology literature to describe salivary gland acinic cell carcinoma with metastases to such distant sites and to discuss the resulting cytologic differential diagnoses.
\end{abstract}

Keywords: Acinic cell carcinoma; Parotid; Cytology; Metastasis; Liver; Vertebrae

Abbreviations: AcCC: Acinic Cell Carcinoma; AFP: Alphafetoprotein; FNA: Fine Needle Aspiration; HCC: Hepatocellular Carcinoma; PAS-D: Periodic Acid-Schiff Staining with Diastase Digestion; RCC: Renal Cell Carcinoma

\section{Introduction}

Salivary gland neoplasms are heterogeneous tumors that vary in anatomic site of origin, histopathology, and behavior, including metastatic potential [1]. While the majority is benign, approximately one-fourth are malignant. Acinic cell carcinoma (AcCC) is a low-grade salivary gland tumor, comprising $1-6 \%$ of salivary neoplasms [2-6]. It is slow-growing but capable of metastasizing, with rare reports involving regional lymph nodes, lungs, and bones [7-14]. To date, there have been only few documented cases of vertebral metastases and limited cytology descriptions of metastatic AcCC. We report a case of recurrent parotid AcCC with widespread liver and bone metastases, diagnosed by fine needle aspiration (FNA) cytology and tissue biopsies.

\section{Case Report}

A 40 year old female smoker with a palpable, slowly enlarging left parotid lesion underwent superficial parotidectomy at an outside facility. The tumor was reported to be a completely excised "parotid adenoma" with close adherence to the facial nerve. Three years later, multiple nodules adjacent to the parotidectomy skin flap incision were observed. Repeat excision demonstrated AcCC. In-house review of the initial excision also showed AcCC. The patient subsequently received radiation therapy.

Twelve years after initial parotidectomy, surveillance CT demonstrated a $1.5-\mathrm{cm}$ left parotid bed lesion and lytic lesions in the left fourth rib and T8 vertebra with increased PET uptake. FNA of the lesions showed AcCC. The patient underwent ablation followed by kyphoplasty.

Over the next three years, the patient had widespread metastases to skull, hip, and sacrum, with parotid recurrences. She underwent chemotherapy, completion parotidectomy, and left neck dissection, demonstrating soft tissue invasion by AcCC without regional lymph node involvement.

Eighteen years after initial diagnosis, ultrasound showed echogenic liver lesions measuring up to $1.8 \mathrm{~cm}$. Hypercellular core biopsy touch preparations (Figures 1-4) demonstrated round to polygonal epithelial cells arranged singly and in branching sheets and occasional clusters with associated capillaries. The cells exhibited relatively monotonous round to oval nuclei with fine chromatin, scattered nucleoli, and abundant granular to focally

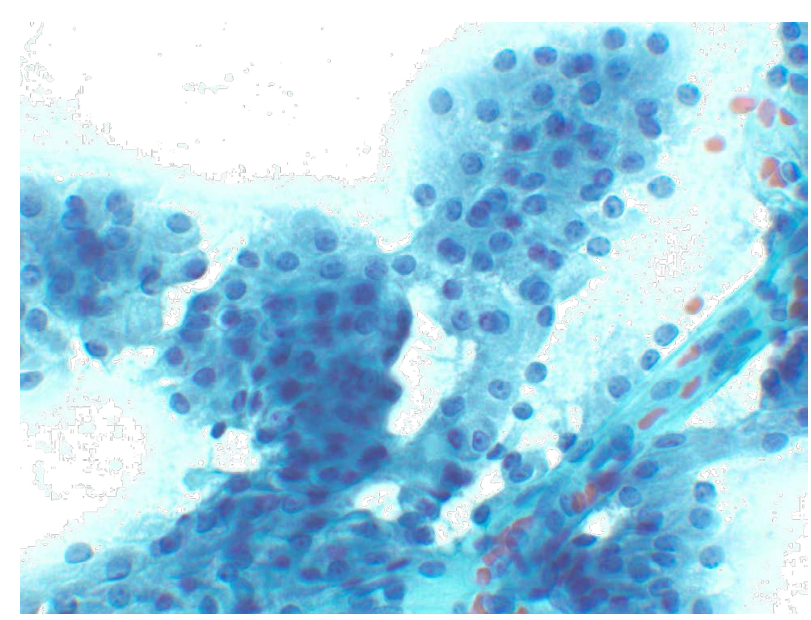

Figure 1: Touch preparation of core needle biopsy of liver lesions (Pap, 40x). Round to polygonal epithelial cells are arranged in branching sheets and clusters around capillaries.

*Corresponding author: David Y. Lu, Department of Pathology and Laboratory Medicine, David Geffen School of Medicine at UCLA, 10833 Le Conte Ave, CHS A3231E, Los Angeles, CA 90095, USA, Tel: 310-206-3362; Fax: 310-267-2058; E-mail: dylu@mednet.ucla.edu

Received January 15, 2014; Accepted March 18, 2014; Published March 20 , 2014

Citation: Torous VF, Conrad R, Wang HL, Lu DY (2014) Widely Metastatic Parotid Acinic Cell Carcinoma to Bone and Liver: A Case Report, Review of Literature, and Review of Diagnostic Challenges. J Cytol Histol S4: 006. doi:10.4172/2157-7099. S4-006

Copyright: (c) 2014 Torous VF, et al. This is an open-access article distributed under the terms of the Creative Commons Attribution License, which permits unrestricted use, distribution, and reproduction in any medium, provided the original author and source are credited. 


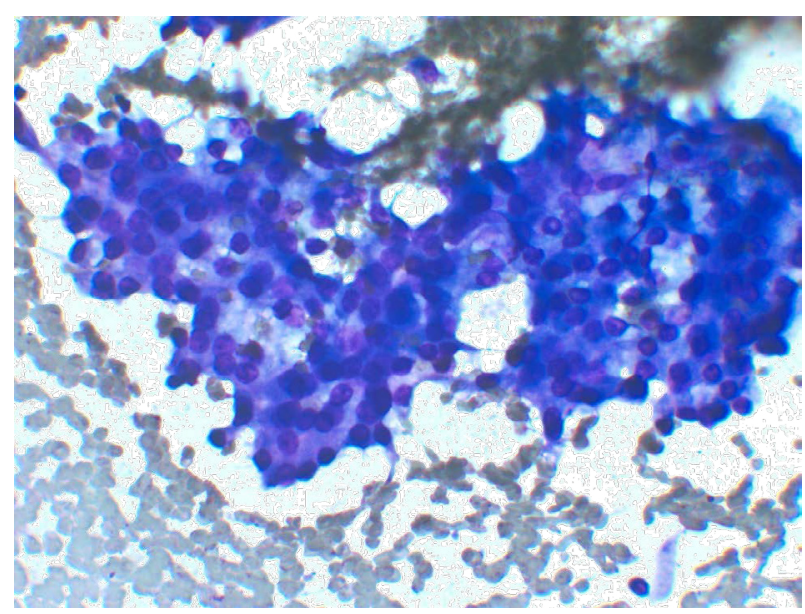

Figure 2: Touch preparation of core needle biopsy of liver lesions (DQ, 40x) Loose clusters of bland cells with round, eccentrically-placed nuclei and moderate to abundant amounts of delicate, vacuolated, lightly basophilic cytoplasm with fine to coarse metachromatic zymogen granules.

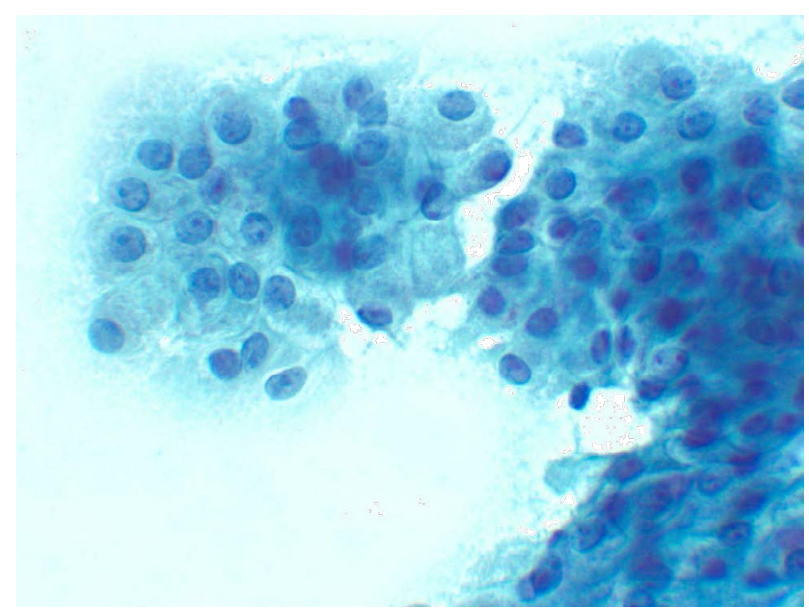

Figure 3: Touch preparation of core needle biopsy of liver lesions (Pap, 60x). Monotonous round to oval nuclei with fine chromatin, regular nuclear borders, scattered prominent nucleoli, and moderate to abundant amounts of granular to focally vacuolated cytoplasm with blue granules.

vacuolated cytoplasm. The background contained bare nuclei, rare lymphocytes, hepatocytes, and granular proteinaceous material. No necrosis, increased mitoses or dedifferentiated areas were observed. The cytomorphologic findings resembled the previous excisions and the corresponding core biopsy confirmed metastatic AcCC (Figure 5). Ablation of liver lesions was performed, and the patient returned to baseline four months later.

\section{Discussion}

First described by Nasse (1892), AcCC is an uncommon salivary gland neoplasm comprising 7-17.5\% of salivary malignancies [15-17]. Eighty percent arise in the parotid gland, with the remainder in the minor salivary, submandibular, and sublingual glands $(6 \%-15 \%, 4 \%$, and $1 \%$, respectively) [18]. It is the most common bilateral malignant salivary tumor [15].

AcCC presents as a slowly enlarging parotid mass with occasional vague, intermittent pain (40\%) and rarely facial muscle weakness or paralysis $(<10 \%)$. It occurs more frequently in women (female-to-male ratio of 3:2) [5] over a wide age range (mean onset in the fourth decade of life) [6], although cases afflicting children and elderly have been reported $[19,20]$.

Grossly, most AcCCs are solitary, well-circumscribed nodules less than $3 \mathrm{~cm}$ in size (range $0.5-13.0 \mathrm{~cm}$ ) with a firm, rubbery consistency. The cut surface is red-tan and lobular, with occasional solid, cystic or hemorrhagic components [19].

Cytological diagnosis of AcCC is problematic, with a high false-negative rate $(\sim 50 \%)$ [21]. On FNA, hypercellular smears demonstrate predominantly serous acinar-type cells, which resemble normal salivary gland acini. The polygonal neoplastic cells exhibit bland, round, eccentrically-placed nuclei and a moderate amount of delicate, vacuolated, lightly basophilic cytoplasm with fine to coarse zymogen granules that stain blue (Papanicolaou) or metachromatic (Romanowsky). Occasional intranuclear pseudoinclusions can be identified. Several other cell types may be present, including intercalated

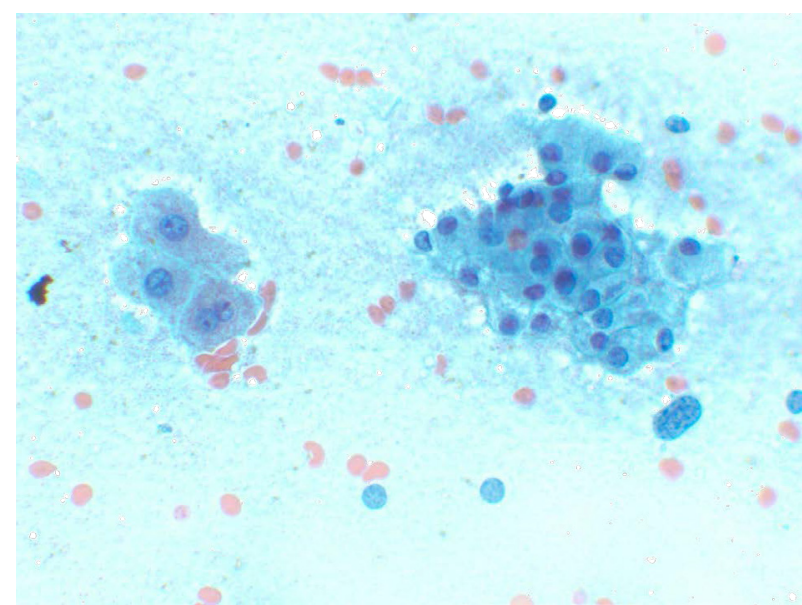

Figure 4: Touch preparation of core needle biopsy of liver lesions (Pap, 40x) Hepatocytes (left) show abundant granular cytoplasm and relatively round nuclei, but are more "oncocytic," with eosinophilic cytoplasm versus the basophilic, vacuolated to granular cytoplasm seen in AcCC (right).

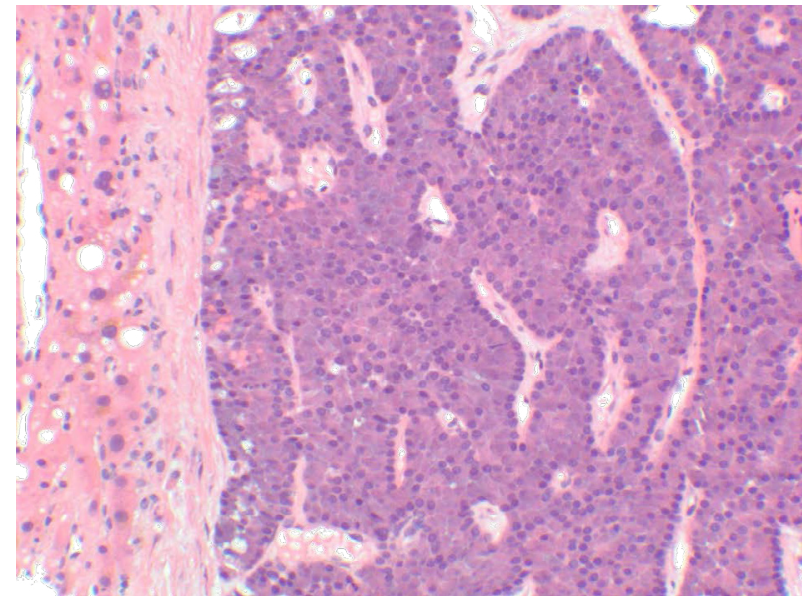

Figure 5: Core needle biopsy of liver lesions (H\&E, 20x). Benign liver parenchyma (left) is involved by acinar structures of well-differentiated AcCC (right). 
duct-type cells, nonspecific glandular cells, vacuolated cells, and clear cells. The neoplastic cells may be arranged singly or in sheets and crowded clusters with indistinct cell borders. Other architectural patterns (encountered on histology) include microcystic, papillary-cystic, and follicular [2]. Mitoses, necrosis, and marked cytologic pleomorphism are infrequent. The background contains bare nuclei, vascular-rich stromal fragments, lymphocytes and foamy proteinaceous material. Rarely, AcCC shows high-grade transformation/dedifferentiation, in which case the underlying diagnosis is not so obvious. Immunostains are nonspecific. Periodic acid-Schiff staining with diastase digestion (PAS-D) can help highlight the cytoplasmic granules [18].

When AcCC metastasizes, the cytologic differential diagnosis must be expanded. In our case with liver metastases, the differential includes a primary hepatic lesion, like hepatocellular carcinoma (HCC). The acinar-type cells of AcCC can superficially resemble hepatocytes (Figure 4), due to abundant granular cytoplasm and relatively round nuclei. Intranuclear pseudoinclusions may also be seen [15], along with rosette/acinar formations [22]

However, hepatocytes are more "oncocytic," with eosinophilic cytoplasm versus the basophilic, vacuolated to granular cytoplasm seen in AcCC. HCC cells occasionally display cytoplasmic bile, Mallory hyaline, or trabecular arrangements surrounded by CD34- positive endothelial cells in a cirrhotic background [15,23]. Immunostaining for HCC includes hepatocyte antigen (HepPar 1) and arginase-1, as well as polyclonal carcinoembryonic antigen and CD10 in a canalicular pattern $[6,23,24]$. PAS-D staining would be more indicative of metastatic AcCC.

Other tumors should also be considered in the cytologic differential diagnosis of metastatic salivary AcCC to the liver. Primary acinar cell carcinoma of the liver is exceedingly rare, characterized by morphological acinar differentiation, architectural pattern and typical cytological features including pyramidal shape, granular cytoplasm, PAS-D staining, trypsin and chymotrypsin positivity $[25,26]$. These features resemble salivary AcCC, which is reported positive for alpha1-antichymotrypsin and alpha-1-antitrypsin [14,27]. Primary acinar cell carcinoma of the liver is favored in the absence of another primary site, such as pancreas or salivary glands, and when resection of the liver lesion causes a rapid decrease in serum alpha-fetoprotein (AFP) levels [26]. In our case, the patient had a history of primary parotid AcCC and never had serum AFP elevation.

Adrenal cortical carcinoma also displays finely granular chromatin, eccentric nuclei and single cells to loose cell-clusters associated with capillaries. Unlike AcCC, it has prominent cytologic atypia, mitoses, necrosis, occasional clear lipid-filled cells, and immunopositivity for synaptophysin, calretinin, inhibin, and Melan A [15].

Occasionally, salivary AcCC demonstrates clear cytoplasm, though this rarely predominates on FNA [6]. Regardless of whether the neoplasm is in the salivary gland or distant metastatic sites, the differential diagnosis in such situations includes metastatic clear cell renal cell carcinoma (RCC) [28]. Metastatic RCC may show greater nuclear pleomorphism and glycogen-containing cells, as well as positive immunostaining for CD10, carbonic anhydrase 9, PAX2, PAX8, and RCC [15].

AcCC of salivary gland origin can also be mistaken for metastatic papillary thyroid carcinoma [6]. Cellular sheets and follicle-like formations can be seen in both, as well as nuclear pseudoinclusion [15] and psammoma bodies [6]. Positivity for thyroid transcription factor-1 (TTF-1) and thyroglobulin, and occasional colloid should correctly identify metastatic thyroid carcinoma [15].
AcCC is generally considered a low-grade neoplasm with good prognosis (95\% survival). However, it has a high recurrence rate (8.3$45 \%)$ [8]. Metastatic rate is $2-20 \%$ [29]. Metastases usually involve cervical lymph nodes, lungs, and bones, and rarely liver $[9,12]$, skin [14], and orbit [13]. Treatment is complete excision with possible lymph node dissection. Radiation, chemotherapy and ablation may be useful palliatively.

Limited discussion exists in the literature regarding cytologic findings and differential diagnosis of widespread metastases of AcCC. There have been only six reports of vertebral AcCC metastases $[2,8$ $10,30]$. We document this case to not only demonstrate such features and diagnostic considerations when encountering metastatic AcCC on FNA, but also to show that despite low-grade histology, there remains the limited possibility of widespread metastasis in patients with a history of AcCC.

\section{References}

1. Guzzo M, Locati LD, Prott FJ, Gatta G, McGurk M, et al. (2010) Major and minor salivary gland tumors. Crit Rev Oncol Hematol 74: 134-148.

2. Spiro RH, Huvos AG, Strong EW (1978) Acinic cell carcinoma of salivary origin A clinicopathologic study of 67 cases. Cancer 41: 924-935.

3. Eveson JW, Cawson RA (1985) Salivary gland tumours. A review of 2410 cases with particular reference to histological types, site, age and sex distribution. $J$ Pathol 146: 51-58.

4. Ellis GL, Auclair PL (1991) Acinic cell carcinoma. In: Ellis GL, Auclair PL, Gnepp $\mathrm{DR}$, editors. Surgical pathology of the salivary glands. WB Saunders Company, Philadelphia, USA.

5. Thompson LDR (2006) Malignant neoplasms of the salivary glands In Thompson LDR. Head and neck pathology. Elsevier Inc Philadelphia, USA

6. Nagel H, Laskawi R, Büter JJ, Schröder M, Chilla R, et al. (1997) Cytologic diagnosis of acinic-cell carcinoma of salivary glands. Diagn Cytopathol 16: 402 412 .

7. Schwentner I, Obrist P, Thumfart W, Sprinzl G (2006) Distant metastasis of parotid gland tumors. Acta Otolaryngol 126: 340-345.

8. Vidyadhara S, Shetty AP, Rajasekaran S (2007) Widespread metastases from acinic cell carcinoma of parotid gland. Singapore Med J 48: e13-15.

9. Zook JD, Djurasovic M, Dimar JR 2nd, Carreon LY (2012) Spinal metastasis from acinic cell carcinoma of the parotid gland: a case report. Spine J 12: e7-10.

10. Grage TB, Lober PH, Arhelger SW (1961) Acinic cell carcinoma of the parotid gland. A clinicopathologic review of eleven cases. Am J Surg 102: 765-768.

11. Buiret G, Céruse P, Ramade A, Carrie C, Pommier P (2012) Acinic cel carcinoma of the parotid gland with skull base invasion: case study, managed by exclusive external 3D radiation therapy. Eur Ann Otorhinolaryngol Head Neck Dis 129: 111-114.

12. Jamieson L, Taylor SM, Smith A, Bullock MJ, Davis M (2007) Metastatic acinic cell carcinoma of the parotid gland with ectopic ACTH syndrome. Otolaryngol Head Neck Surg 136: 149-150.

13. Saleh TA, Hakin KN, Davidson MJ (2003) Metastasis of acinic cell carcinoma of the parotid gland to the contralateral orbit. Arch Ophthalmol 121: 1783-1786.

14. Varsegi MF, Ravis SM, Hattab EM, Henley JD, Billings SD (2008) Widespread cutaneous metastases from acinic cell carcinoma 20 years after primary presentation. J Cutan Pathol 35: 591-593.

15. DeMay RM (2012) The art \& science of cytopathology. (2ndedn) American society for clinical pathology. Chicago

16. Sams RN, Gnepp DR (2013) P63 expression can be used in differential diagnosis of salivary gland acinic cell and mucoepidermoid carcinomas. Head Neck Pathol 7: 64-68.

17. Lin WN, Huang HC, Wu CC, Liao CT, Chen IH, et al. (2010) Analysis of acinic cell carcinoma of the parotid gland - 15 years experience. Acta Otolaryngol 130: $1406-1410$ 
Citation: Torous VF, Conrad R, Wang HL, Lu DY (2014) Widely Metastatic Parotid Acinic Cell Carcinoma to Bone and Liver: A Case Report, Review of Literature, and Review of Diagnostic Challenges. J Cytol Histol S4: 006. doi:10.4172/2157-7099.S4-006

18. Thompson LDR, Wenig BM (2013) Diagnostic pathology: head and neck (1st ed.) Amirsys Publishing Inc Salt Lake City.

19. Ellis GL, Auclair PL (2008) Tumors of the salivary glands. American Registry of Pathology. Washington, DC, USA.

20. Abrams AM, Cornyn J, Scofield HH, Hansen LS (1965) Acinic Cell Adenocarcinoma of the Major Salivary Glands. A Clinicopathologic Study of 77 Cases. Cancer 18: 1145-1162.

21. Hughes JH, Volk EE, Wilbur DC (2005) Pitfalls in salivary gland fine-needle aspiration cytology: lessons from the college of american pathologists interlaboratory comparison program in nongynecologic cytology. Arch Pathol Lab Med 129: 26-31.

22. Schreiner AM, Yang GC (2012) Hepatocellular carcinoma with striking rosettelike structures on smears. Diagn Cytopathol 40: 991-992.

23. Romanas MM, Cherian R, McGregor DH, Wu Y, May CL, et al. (2004) Hepatocellular carcinoma diagnosed by fine-needle aspiration of the parotid gland. Diagn Cytopathol 30: 401-405.

24. Vitale AR, Compilato D, Coletti G, Calvisi G, Ciuffitelli V, et al. (2009) Metastatic hepatocellular carcinoma of the parotid region without lung metastasis: a case report. Int J Oral Maxillofac Surg 38: 696-698.

25. Agaimy A, Kaiser A, Becker K, Bräsen JH, Wünsch PH, et al. (2011) Pancreatictype acinar cell carcinoma of the liver: a clinicopathologic study of four patients. Mod Pathol 24: 1620-1626.

26. Hervieu V, Lombard-Bohas C, Dumortier J, Boillot O, Scoazec JY (2008) Primary acinar cell carcinoma of the liver. Virchows Arch 452: 337-341.

27. Ellis G, Simpson RHW (2005) Acinic cell carcinoma. In: World health organization classification of tumours: pathology and genetics of head and neck tumours. Lyon: IARC Press.

28. Ellis GL (1998) Clear cell neoplasms in salivary glands: clearly a diagnostic challenge. Ann Diagn Pathol 2: 61-78.

29. Bradley PJ (2001) Distant metastases from salivary glands cancer. ORL J Otorhinolaryngol Relat Spec 63: 233-242.

30. Tavora F, Rassaei N, Shilo K, Foss RD, Galvin JR, et al. (2007) Occult primary parotid gland acinic cell adenocarcinoma presenting with extensive lung metastasis. Arch Pathol Lab Med 131: 970-973.
This article was originally published in a special issue, Histology and Histopathology handled by Editor(s). Borislav A. Alexiev, University of Maryland Medical Center, USA 